\title{
Review \\ The role of tumor necrosis factor-alpha in systemic lupus erythematosus
}

Martin Aringer ${ }^{1}$ and Josef S Smolen ${ }^{2}$

\author{
${ }^{1}$ Division of Rheumatology, Department of Medicine III, University Clinical Center Carl Gustav Carus, Technical University of Dresden, Fetscherstrasse \\ 74, 01307 Dresden, Germany \\ ${ }^{2}$ Department of Rheumatology, Internal Medicine III, Medical University of Vienna, Waehringer Guertel 18-20, 1090 Vienna, Austria
}

Corresponding author: Martin Aringer, martin.aringer@uniklinikum-dresden.de

Published: 23 January 2008

This article is online at http://arthritis-research.com/content/10/1/202

(c) 2008 BioMed Central Ltd

Arthritis Research \& Therapy 2008, 10:202 (doi:10.1186/ar2341)

\begin{abstract}
Murine models of systemic lupus erythematosus (SLE) have shown apparently contradictory evidence in that either (a) tumor necrosis factor (TNF) expression was low and TNF administration helpful or (b) TNF was high and TNF blockade of therapeutic benefit, depending on the mouse model investigated. In fact, TNF apparently has both effects, checking autoimmunity, at least to some degree, and fostering inflammation. TNF blockade regularly, but transiently, induces or increases autoantibodies to chromatin and to phospholipids. At the same time, open-label data suggest that TNF blockade suppresses inflammatory manifestations of SLE, and long-term benefit was seen in patients with lupus nephritis. A controlled clinical trial is under way.
\end{abstract}

Tumor necrosis factor (TNF) exerts a variety of physiologic and pathogenic effects [1-6]. For example, TNF plays a major role in the organogenesis of the lymphoid system in early development; it has pro-apoptotic and anti-apoptotic effects, depending on the underlying contextual situation; it controls the activation and responsiveness of many cells, including cells of the immune system; and it is a master switch in the initiation and perpetuation of inflammatory responses (Figure 1). When the role of TNF and TNF inhibition in systemic lupus erythematosus (SLE)-especially the latter two effects-is examined, modulation of the immune (and autoimmune) reactivity and pro-inflammatory effects have to be considered. Therefore, these effects will constitute the focus of the current review.

\section{The role of tumor necrosis factor in controlling autoimmunity}

Autoreactivity is a common feature of healthy individuals, both on the cellular and humoral levels $[7,8]$. However, this type of autoimmunity is usually well controlled, is often only transient, and does not lead to disease. In contrast, in autoimmune diseases, autoimmunity has escaped its stringent control and become pathogenic.

For SLE, there exist a variety of murine models. They differ in parts of their phenotype and especially in the underlying genetic factors, which lead to their disease. With respect to TNF, it is of particular interest that this cytokine appears to play an immunoregulatory role in lupus-prone animals (Table 1). However, this role is not at all uniform, and TNF has different consequences depending upon the strain and the stage of the disease.

\section{Tumor necrosis factor can ameliorate murine lupus}

In 1988, Jacob and McDevitt [9] reported that NZB/W mice showed diminished production of TNF, a defect stemming from the otherwise healthy NZW parent, and proved that NZB/W disease was at least partly reversible by administration of recombinant TNF early in life. Gordon and colleagues [10], upon repeating and expanding these studies, saw similar beneficial effects of high-dose TNF, even after nephritis had developed, but there was no long-term protection against the disease. Gordon and Wofsy [11] also found that the recombinant TNF had effects on cellular, but not humoral, (auto)immunity. More recently, Kontoyiannis and Kollias [12], by analyzing TNF-deficient NZB mice, re-established the finding that TNF deficiency is an important driver of lupus-like autoimmunity in certain strains. Whereas TNFcompetent NZB mice display a subtle autoimmune phenotype only, TNF-deficient NZB mice developed severe lupus.

$\mathrm{ACLA}=$ anti-cardiolipin-antibody $; \mathrm{ANA}=$ anti-nuclear antibody $\mathrm{CD}=$ Crohn disease $; \mathrm{CLIFT}=$ Crithidia luciliae immunofluorescence test; dsDNA $=$ double-stranded DNA; IFN = interferon; Ig = immunoglobulin; MMF = mycophenolate mofetil; RA = rheumatoid arthritis; RIA = radioimmunoassay; $\mathrm{SCLE}=$ subacute cutaneous lupus erythematosus; $\mathrm{SLE}=$ systemic lupus erythematosus; $\mathrm{SpA}=$ spondylarthropathy; $\mathrm{TCR}=\mathrm{T}$-cell receptor; TNF $=$ tumor necrosis factor; $\mathrm{WHO}=$ World Health Organization. 
Figure 1

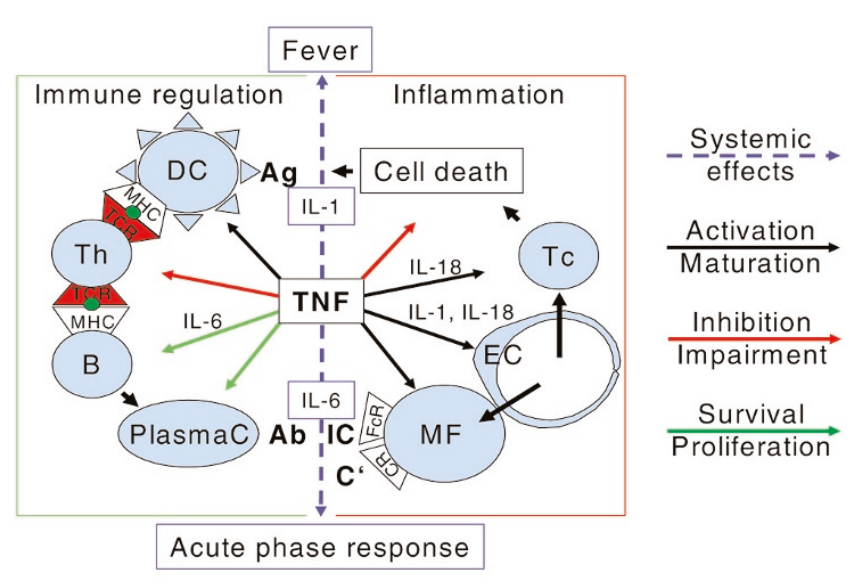

Relevant effects of tumor necrosis factor (TNF). TNF acts on the hypothalamus to induce fever and on hepatocytes to induce an acutephase response, mainly via interleukin (IL)-1 and IL-6, respectively (blue lines). TNF also exerts a wide variety of immunoregulatory (left) and pro-inflammatory actions: TNF is involved in the maturation of dendritic cells (DC) and activates endothelial cells (EC) and immune cells (black lines). Chronic TNF often is a survival signal (green lines) and plays a role in maintaining survival niches for long-lived plasma cells (PlasmaC). Some of these effects are indirect in part, involving cytokines such as IL- 6 for B cells (B) and IL-18 for cytotoxic T cells (Tc). On the other hand, chronic TNF exposure leads to the disassembly of T-cell receptors (TCR), thus inhibiting T-cell responses, and induces the expression of anti-apoptotic proteins, inhibiting programmed cell death (red lines). Effects on many other cells, such as fibroblasts or osteoclasts, were left out because of the focus on immune regulation but are of major importance elsewhere. Ab, antibodies; Ag, antigen; C', complement; CR, complement receptors; FcR, Fc receptor; IC, immune complex; MF, macrophage; MHC, major histocompatibility complex; Th, T helper cell.

\section{Tumor necrosis factor can deteriorate murine lupus}

In contrast to the findings in NZB/W mice, in which the autoimmune consequences of low TNF levels were profound, TNF was found to be highly overexpressed in both sera and renal tissue of MRL//pr/lpr lupus mice and the levels of TNF correlated with the degree of inflammatory organ disease [13,14]. Moreover, even in NZB/W mice, there is an increase in renal TNF expression in conjunction with renal inflammation [15].

In fact, anti-TNF therapy was beneficial in MRL//pr lupus. TNF-targeted approaches improved inflammation in joints [16] and lungs [17]. Likewise, TNF blockade improved arthritis, pneumonitis, and skin disease of moth-eaten mice [18] and nephritis and leukopenia in the C3H.SW mouse [19], two additional lupus models. Of particular interest, administration of low-dose TNF later in the course of NZB/W disease accelerated renal demise [15], revealing that even in this model, in which TNF was thought to be protective, the cytokine has a dual role-beneficial and detrimental.

\section{Autoantibodies under tumor necrosis factor blockade in more organ-selective autoimmune disease}

When therapies that inhibited TNF, such as infliximab, etanercept, and adalimumab, were introduced in patients with rheumatoid arthritis (RA), spondylarthropathies (SpAs), or Crohn disease (CD), the emergence of anti-nuclear antibodies (ANAs) and anti-dsDNA (double-stranded DNA) was observed [20-31].

New-onset ANAs were found in at least one fourth, and up to two thirds, of ANA-negative patients, and this possibly depended somewhat on the disease (Table 2). Autoantibodies to dsDNA, which are much more specific for SLE, still emerged in $9 \%$ to $54 \%$ of the patients under infliximab therapy, depending on the test system. By means of the Crithidia luciliae immunofluorescence test (CLIFT), Charles and colleagues [20] found anti-dsDNA in 22 of 156 patients with RA (14\%) whereas by radioimmunoassay (RIA) only 8 patients $(5 \%)$ had clearly positive antibodies $(>25 \mathrm{U} / \mathrm{mL})$.

It is important to note that the vast majority of these antidsDNA antibodies were of immunoglobulin (Ig) $M$ isotype (Table 1) and most probably were non-pathogenic. In contrast to these IgM autoantibodies, the occurrence of $\lg G$ antidsDNA antibodies appeared to be a relatively rare event. However, these autoantibodies may be closely associated with instances of SLE-like disease $[20,27]$. In this regard, it is interesting that, whereas IgM anti-dsDNA autoantibodies were found less frequently under TNF blockade with etanercept [28], this compound induces lupus to an apparently similar extent as antibodies to TNF [32]. In addition, formation of antiphospholipid antibodies, again mostly of IgM isotype, can occur during TNF-inhibiting therapy [24,33] and very rarely may lead to life-threatening vascular complications [33,34].

\section{Drug-induced lupus and lupus nephritis under tumor necrosis factor blockade}

The induction of lupus-like disease by TNF blockers appears to be quite uncommon, with an incidence of $0.5 \%$ to $1 \%$ $[20,25,35]$, and independent of the type of TNF-blocking drug $[32,36]$. Moreover, TNF-blocker-induced lupus is usually benign, with most patients developing fatigue or fever, musculoskeletal or skin symptoms, changes in blood counts, or serositis, but only rarely major organ disease, and these symptoms resolve after TNF blockade is stopped $[32,36]$.

Nevertheless, seven cases of nephritis occurring under antiTNF therapy have been reported [37-39]. Four of these cases occurred under etanercept, two on infliximab, and one under adalimumab. Of these seven patients, five treated with etanercept or adalimumab had bona fide lupus nephritis. Histology showed World Health Organization (WHO) class IV (diffuse proliferative) glomerulonephritis in two cases and class III and class V (membranous) nephritis in one case each. One patient did not undergo renal biopsy. Despite 
Table 1

Tumor necrosis factor (TNF) expression and effects of recombinant TNF administration or TNF blockade in murine models of systemic lupus erythematosus

\begin{tabular}{llll}
\hline Model [Reference] & TNF expression & Effects of recombinant TNF & Effects of TNF blockade/deficiency \\
\hline NZB [12] & Normal & NA & Severe lupus in TNF TN- $^{-/}$animals \\
NZB/W [9,10] & Low & $\begin{array}{l}\text { High dose: late onset (if given early), } \\
\text { prolonged survival } \\
\text { Low dose (late): increased renal inflammation }\end{array}$ \\
{$[15]$} & High in nephritis & NA & Improved arthritis, pneumonitis \\
MRL/lpr [13,14] & High & NA & Improved skin, arthritis, pneumonitis \\
Moth-eaten [18] & High & NA & Less severe nephritis, leukocytopenia \\
C3H.SW [19] & High & &
\end{tabular}

NA, not assessed.

Table 2

Autoantibodies and drug-induced lupus under infliximab

\begin{tabular}{|c|c|c|c|c|c|c|c|c|c|}
\hline \multirow[b]{2}{*}{ Diagnosis } & \multirow[b]{2}{*}{ Number } & \multirow{2}{*}{$\frac{\text { New ANA }}{\text { Positive }}$} & \multicolumn{3}{|c|}{ New anti-dsDNA } & \multicolumn{2}{|c|}{ New ACLA } & \multirow[b]{2}{*}{ DIL } & \multirow[b]{2}{*}{ Reference } \\
\hline & & & Positive $^{a}$ & $\lg M$ & $\lg G$ & $\lg M$ & $\lg G$ & & \\
\hline RA & 156 & $37(24 \%)$ & $22(14 \%)$ & 22 & 1 & ND & ND & 1 & [20] \\
\hline RA & 62 & $19(31 \%)$ & $7(11 \%)$ & 7 & 0 & ND & ND & 0 & {$[22]$} \\
\hline RA & 24 & $4(17 \%)$ & $13(54 \%)$ & $9-11$ & $3-4$ & 5 & 0 & 0 & [24] \\
\hline RA & 59 & $24(41 \%)$ & $21(36 \%)$ & 19 & 2 & ND & ND & 0 & [26] \\
\hline RA & 53 & $29(55 \%)$ & $5(9 \%)$ & $22^{\mathrm{b}}$ & $34^{b}$ & 0 & 0 & 2 & [27] \\
\hline RA & 59 & $24(41 \%)$ & $29(49 \%)$ & 28 & 1 & 0 & 0 & 0 & {$[28]$} \\
\hline RA & 57 & $28(49 \%)$ & & ND & 3 & ND & ND & 1 & [31] \\
\hline All RA & 413 & $165(40 \%)$ & $77(19 \%)$ & & & & & $4(1.0 \%)$ & \\
\hline AS & 15 & $9(60 \%)$ & $4(27 \%)$ & 4 & $0-1$ & 1 & 3 & 0 & [24] \\
\hline SpA & 21 & $12(57 \%)$ & $4(19 \%)$ & ND & ND & ND & ND & 0 & [21] \\
\hline SpA & 35 & $25(71 \%)$ & $6(17 \%)$ & 6 & 0 & ND & ND & 0 & [22] \\
\hline SpA & 33 & 8 (24\%) & 11 (33\%) & 11 & 0 & ND & ND & 0 & [29] \\
\hline All SpA & 94 & $54(57 \%)$ & $25(27 \%)$ & & & & & $0(0 \%)$ & \\
\hline CD & 35 & $6(17 \%)$ & 3 (9\%) & ND & ND & ND & ND & 0 & [23] \\
\hline CD & 125 & $71(57 \%)$ & $14(11 \%)$ & ND & ND & ND & ND & 2 & [25] \\
\hline CD & 500 & ND & ND & ND & ND & ND & ND & 3 & [35] \\
\hline$C D$ & 63 & 21 (33\%) & $9(14 \%)$ & ND & 9 & 2 & 0 & 1 & [30] \\
\hline All CD & 723 & & & & & & & $6(0.8 \%)$ & \\
\hline All together & 1,230 & & & & & & & $10(0.8 \%)$ & \\
\hline
\end{tabular}

aRadioimmunoassay or most conservative value reported; bvalues difficult to reconcile with the number of patients with anti-dsDNA antibodies as measured by radioimmunoassay. ACLA, anti-cardiolipin antibodies; ANA, anti-nuclear antibodies; anti-dsDNA, antibodies to double-stranded DNA; AS, ankylosing spondylitis; CD, Crohn disease; DIL, drug-induced lupus; Ig, immunoglobulin; ND, not determined/reported; RA, rheumatoid arthritis; SpA, spondylarthropathies.

these impressive histological findings, none of the five patients had to undergo cyclophosphamide therapy, only one was treated with mycophenolate mofetil (MMF) [39], and the rest remitted under steroids and TNF blocker withdrawal only. 


\section{Rationale for using tumor necrosis factor inhibition to treat systemic lupus erythematosus}

Most clinical manifestations of SLE are the consequence of inflammatory changes subsequent to immune complex formation with $\mathrm{Fc}_{\mathrm{c}}$ receptor and complement activation. In the sera of SLE, in contrast to many other diseases, such as RA, in which the pathogenic role of TNF is established despite the difficulty to readily detect increases in serum levels, TNF reaches levels of more than $100 \mathrm{pg} / \mathrm{mL}$; moreover, TNF concentrations are significantly associated with clinical disease activity [40-44]. Despite the very high serum levels of soluble TNF receptors, which likewise correlate with disease activity $[42,43,45]$, the TNF circulating in lupus sera is bioactive [46].

TNF is evidently overexpressed not only in murine (see above), but also in human lupus nephritis [47-50], and our own data suggest that this increase is associated with (renal) disease activity as estimated by histology [51]. In addition, TNF expression was demonstrated in refractory subacute cutaneous lupus erythematosus (SCLE) lesions [52].

Given the role of TNF as a strong mediator of inflammation, the high levels of serum TNF in active SLE, and the overexpression in renal tissue with active nephritis, we reasoned that TNF blockade could be an efficient way to block inflammation in afflicted organs, such as the kidney, the joints, or the skin. However, in view of the autoimmunogenic potential of inhibiting TNF, we tested TNF inhibition as a means to interfere with the inflammatory response in SLE by administering only an induction regime of four infusions of infliximab within 10 weeks rather than by planning for long-term therapy.

\section{Evidence for beneficial effects from open-label trial and anecdotal reports}

Before we can embark upon summarizing reports on individual or small groups of cases, a word of caution is mandated. Anecdotal reports or open-label trials cannot be regarded as providing evidence of the results they claim to reflect. If they use some objective measure, the hints they give may be slightly stronger, but the ultimate information has to come from randomized controlled clinical trials [53]. On the other hand, open-label studies in RA [54], ankylosing spondylitis [55], and CD were subsequently confirmed by controlled trials. Moreover, the potential risks of the approach and the heterogeneity of SLE with its life-threatening features justified an open-label study as a first step. Finally, open-label experience with TNF blockade in a homogeneous subset of the disease (such as nephritis) with the use of objective laboratory measures (such as levels of creatinine or proteinuria) would allow for focussing a controlled trial once they reveal beneficial effects. From this perspective, we embarked upon an openlabel trial several years ago and complemented the data obtained with the anecdotal reports on individual cases that were published in the literature. Although the evidence for therapeutic efficacy of TNF blockade in SLE is still limited, there are a minimum of 28 cases reported at least in abstract form [56-61] and most of these are on the use of the chimeric monoclonal antibody infliximab.

\section{Tumor necrosis factor blockade and lupus arthritis}

Our own experience includes three patients with refractory lupus polyarthritis, all of whom went into complete remission within days after the first (approximately $5 \mathrm{mg} / \mathrm{kg}$ ) infusion of infliximab [56]. Similar to RA, this effect lasted for about 8 weeks after the last infusion of a series of four. Retreatment was effective for the relapsing disease in a single patient for whom this approach was tried but led to a further increase in anti-dsDNA autoantibodies [62]. All of our patients were on constant dosages of either azathioprine or methotrexate, as were patients successfully treated in Brussels [59] and Kuwait [60]. In contrast, Katz and colleagues [63] saw a frequent decline in efficacy and severe infusion reactions in patients who were treated with infliximab without such combination with conventional disease-modifying anti-rheumatic drugs.

\section{Tumor necrosis factor blockade and skin involvement}

The published experience on lupus skin disease includes two patients with SCLE $[64,65]$ who were successfully treated with the combination of infliximab and azathioprine and with etanercept, respectively. We have also seen overt and longlasting improvement of a butterfly rash following compassionate care treatment with infliximab and azathioprine in a patient with lupus nephritis.

\section{Tumor necrosis factor blockade and lupus nephritis}

Twelve published patients with SLE treated with TNF blockers had lupus nephritis. Among them were seven patients with diffuse proliferative (WHO class IV) $[56,58$, 59,61 ] and at least four with membranous (WHO class V) lupus nephritis $[56,57,59]$. Most patients were treated with the combination of infliximab with azathioprine or MMF. One pregnant patient received etanercept plus plasmapheresis and intravenous immunoglobulin [58].

In all but three patients, TNF blocker therapy led to significant long-term renal responses. This may easily reflect reporting bias, but in a series of nine patients with lupus nephritis, in which all SLE patients of the cooperating centers were included if they had ever received infliximab, the data still amounted to a success rate of two out of three [59].

It is important to stress an unexpected finding in the patients with lupus nephritis who were successfully treated with only four infusions of infliximab (and constant-dose azathioprine). In lupus arthritis, the disease relapsed within 2 months after the last infusion, whereas in lupus nephritis, the improvement achieved lasted for several years in some of the patients $[59,62]$. In fact, many patients further improved their 
proteinuria over time, with stable normal or slightly improving renal function [56]. These findings, which suggest selfperpetuation of the inflammatory events which is interfered with by TNF blockade, have yet to be understood in detail.

It is also noteworthy that severe edema in one case of longstanding nephritic syndrome resolved within 2 weeks despite a much slower increase in serum albumin [56], suggesting direct effects on vessel permeability [66]. Thus, TNF blockers, and infliximab in particular, appear to rapidly reduce inflammation, and probably also reduce vascular permeability, in patients with inflammatory manifestations of SLE.

\section{Autoantibodies under tumor necrosis factor blockade in patients with systemic lupus erythematosus}

While dampening inflammation, TNF blockade with infliximab induced an increase of autoantibodies in five out of seven patients and increases in anti-cardiolipin-antibodies (ACLAs) in four out of seven patients in our open-label trial $[62,67]$. Moreover, we observed increases in autoantibodies to histones and/or chromatin in all seven patients, including those without anti-dsDNA antibodies [62]. At least in part, the increase in anti-histone and anti-chromatin antibodies preceded the anti-dsDNA increase.

All of these antibodies were only transiently elevated and fell back to baseline levels shortly after TNF blockade was stopped. None of the patients experienced a lupus flare, and serum complement levels remained stable [62,67]. Nevertheless, the induced antibodies to dsDNA were of high affinity, as measured by RIA, and of $\lg$ isotype, as determined by CLIFT. Although this could have been expected given the preformed anti-dsDNA antibodies, the absence of lupus flares requires clarification. Several explanations are possible. First, at the time of inclusion into this study, some patients may have had a non-pathogenic autoantibody profile, which, even when activated and expanded, remained nonpathogenic. Second, the increase in autoantibody levels was only transient, whereas the longer-term presence of high levels of pathogenic antibodies might be required to induce complement activation and flares; such a notion is supported by observations on the long-term presence of anti-dsDNA antibodies before the onset of SLE symptoms [68]. Third, the pronounced anti-inflammatory effects of infliximab may have prevented damage despite the presence of potentially pathogenic antibodies. Nevertheless, we have observed one episode of deep vein thrombosis in temporal association with a slight increase in ACLA in one patient with preformed lgG ACLA [59], indicating that in individual patients the presence of autoantibodies may be associated with clinical pathology.

\section{Potential mechanisms of autoantibody formation under tumor necrosis factor blockade}

Several hypotheses have been proposed which may explain, at least in part, how a (therapeutic) reduction in TNF activity could lead to formation of autoantibodies against nuclear components and phospholipids. One of these hypotheses relates to the activation of interferon (IFN)- $\alpha$. Because, under normal circumstances, TNF downregulates IFN- $\alpha$ [69], it was hypothesized that the reduction in TNF unleashed IFN- $\alpha$, thus fostering autoimmunity. However, in SLE, both IFN- $\alpha$ and TNF are highly increased and the levels of both of these cytokines are associated with disease activity [40-42,44]. This finding not only challenges the hypothesis, but even suggests that the reciprocal negative regulation of the two cytokines is not functional in active SLE. Rather, the combined increase of both TNF and IFN- $\alpha$ might contribute to the pathogenesis of systemic autoimmunity.

Another hypothesis relates to prolonged B-cell survival upon TNF inhibition. In a murine graft-versus-host disease system, TNF blockade led to diminished production of IFN- $\gamma$, diminished IFN- $\gamma$-induced CD95 (Fas) upregulation, and diminished cytolytic activity, but to a significant increase in anti-dsDNA antibodies [70]. This led the authors to hypothesize that TNF blockade hampers the elimination of autoimmune B lymphocytes by cytotoxic T cells [70]. Because IL18 , formerly called IFN- $\gamma$-inducing factor, is reduced by TNF blockade in RA as well as in SLE $[51,71]$, this mechanism may play a role.

Chronic TNF exposure also directly impairs T-cell activation by downmodulating $\mathrm{T}$-cell receptor (TCR) components, impairing TCR signalling, and attenuating antigen-driven events [72,73]. Thus, inhibition of TNF may facilitate T-cell activation. Finally, TNF blockade after chronic TNF exposure may also lead to increased apoptosis [62]. The resulting increase in apoptotic material could explain why the emerging antibodies appear to exclusively target nuclear antigens and phospholipids, both of which are expressed on apoptotic bodies [74,75]. Thus, the combination of an increase in accessible antigen, normalization in TCR function, and better B-cell activation may help to explain the pathways to increased lupus autoantibodies under TNF blockade.

\section{Safety issues of tumor necrosis factor blocker therapy for systemic lupus erythematosus}

In our limited experience, treatment with only four infusions of infliximab in combination with azathioprine or methotrexate appeared to be fairly safe with regard to lupus flares [56] despite the increase of autoantibodies [62]. However, although it may hold true that the strong anti-inflammatory effects of infliximab protect against the transient increase in autoantibodies, occasional flares might well occur when more patients are treated. Looking at potential consequences of a likewise transient increase in ACLA, we have actually seen one (single) episode of deep vein thrombosis [59], alerting to such a possibility.

On the other hand, we did observe bacterial infections. Even under short-term therapy (four infusions), we have seen a 
Figure 2
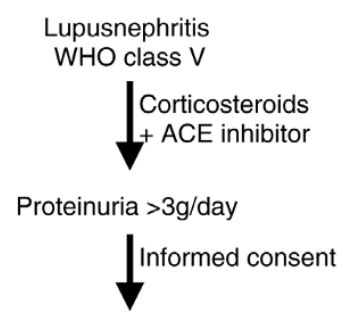

$1: 1$

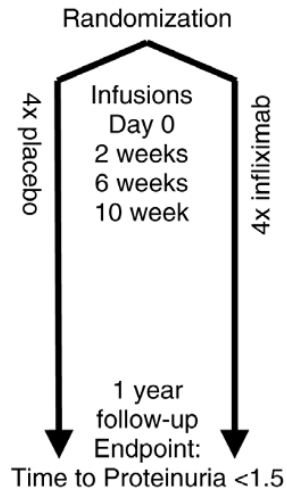

Graphic representation of the study plan of the ongoing TRIAL V (Tumor necrosis factor blockade with Remicade In Active Lupus nephritis class V) randomized placebo-controlled clinical trial. More details can be found at [76]. ACE, angiotensin-converting enzyme; WHO, World Health Organization.

number of urinary tract infections, one leading to bacteremia, and an occasional episode of enteritis caused by Salmonella enteritidis [59]. Longer-term therapy may in fact expose patients to higher risks in this respect [59].

Infusion reactions were not seen when infliximab was combined with azathioprine (or methotrexate). Only a single episode occurred in a patient retreated 1.5 years after cessation of infliximab [59]. This is likely due to the combination given that others have regularly observed severe infusion reactions in lupus arthritis patients for whom infliximab was used in monotherapy [63].

\section{Controlled trial of infliximab and azathioprine in membranous lupus nephritis}

These data indicate that short-term TNF blockade in combination with azathioprine may be a step forward in the therapy of patients with lupus nephritis. However, substantial evidence can be derived only from a controlled clinical trial. We recently embarked on a double-blind placebo-controlled study called 'TNF blockade with Remicade in Active Lupus nephritis class V', or TRIAL V. This study includes patients with membranous lupus nephritis (WHO class $\mathrm{V}$ ) in whom corticosteroids and angiotensin-converting enzyme inhibitors have failed to reduce proteinuria below $3 \mathrm{~g} /$ day. Patients are randomly assigned either to the combination of azathioprine plus four infusions $(5 \mathrm{mg} / \mathrm{kg}$ ) of infliximab or to azathioprine monotherapy plus four placebo infusions (Figure 2). The primary endpoint is time to reduction in proteinuria below $1.5 \mathrm{~g} /$ day.

\section{Conclusion}

Although our understanding of TNF in SLE has increased considerably over the past few years, novel findings are well in line with what had to be predicted from previous mouse studies. On the one hand, TNF apparently has antiautoimmune effects and TNF blockade may lead to the occurrence of autoantibodies. Whereas drug-induced lupuslike disease is an uncommon, but established, adverse effect of TNF blockade in patients with RA, SpA, or CD, these autoantibodies hitherto have not induced lupus flares. On the other hand, TNF appears to play a major pro-inflammatory role in SLE also. The available open-label experience on infliximab therapy in SLE suggests that, in combination with azathioprine, infliximab may turn out to be an interesting therapeutic option in selected patients with SLE and in particular in those with nephritis. It will depend on controlled clinical trials to decide this point. At least one such trial is under way.

\section{Competing interests}

Both authors have received a research grant from Centocor for laboratory studies and Centocor also funds the controlled trial. JSS has also received occasional advisory fees from Centocor and other companies marketing TNF blockers.

\section{References}

1. Theofilopoulos AN, Lawson BR: Tumour necrosis factor and other cytokines in murine lupus. Ann Rheum Dis 1999, 58 Suppl 1:|49-155.

2. McDevitt $H$, Munson $S$, Ettinger $R$, Wu A: Multiple roles for tumor necrosis factor-alpha and lymphotoxin alpha/beta in immunity and autoimmunity. Arthritis Res 2002, 4:S141-S152.

3. Mageed RA, Isenberg DA: Tumour necrosis factor alpha in systemic lupus erythematosus and anti-DNA autoantibody production. Lupus 2002, 11:850-855.

4. Aringer M, Smolen JS: Complex cytokine effects in a complex autoimmune disease: tumor necrosis factor in systemic lupus erythematosus. Arthritis Res Ther 2003, 5:172-177.

5. Suryaprasad AG, Prindiville T: The biology of TNF blockade. Autoimmun Rev 2003, 2:346-357.

6. Kollias G: TNF pathophysiology in murine models of chronic inflammation and autoimmunity. Semin Arthritis Rheum 2005, 34:3-6.

7. Coutinho A, Kazatchkine MD, Avrameas S: Natural autoantibodies. Curr Opin Immunol 1995, 7:812-818.

8. Schwartz M, Cohen IR: Autoimmunity can benefit self-maintenance. Immunol Today 2000, 21:265-268.

9. Jacob CO, McDevitt HO: Tumour necrosis factor-alpha in murine autoimmune 'lupus' nephritis. Nature 1988, 331:356-358.

10. Gordon C, Ranges GE, Greenspan JS, Wofsy D: Chronic therapy with recombinant tumor necrosis factor-alpha in autoimmune NZB/NZW F1 mice. Clin Immunol Immunopathol 1989, 52:421-434.

11. Gordon C, Wofsy D: Effects of recombinant murine tumor necrosis factor-alpha on immune function. J Immunol 1990, 144:1753-1758.

12. Kontoyiannis D, Kollias G: Accelerated autoimmunity and lupus nephritis in NZB mice with an engineered heterozygous deficiency in tumor necrosis factor. Eur J Immunol 2000, 30:20382047. 
13. Boswell JM, Yui MA, Burt DW, Kelley VE: Increased tumor necrosis factor and IL-1 beta gene expression in the kidneys of mice with lupus nephritis. J Immunol 1988, 141:3050-3054.

14. Yokoyama $\mathrm{H}, \mathrm{Kreft} B$, Kelley VR: Biphasic increase in circulating and renal TNF-alpha in MRL-Ipr mice with differing regulatory mechanisms. Kidney Int 1995, 47:122-130.

15. Brennan DC, Yui MA, Wuthrich RP, Kelley VE: Tumor necrosis factor and IL-1 in New Zealand Black/White mice. Enhanced gene expression and acceleration of renal injury. $J$ Immunol 1989, 143:3470-3475.

16. Edwards CK, III, Zhou T, Zhang J, Baker TJ, De M, Long RE, Borcherding DR, Bowlin TL, Bluethmann H, Mountz JD: Inhibition of superantigen-induced proinflammatory cytokine production and inflammatory arthritis in MRL-Ipr/lpr mice by a transcriptional inhibitor of TNF-alpha. J Immunol 1996, 157: 1758-1772.

17. Deguchi $\mathrm{Y}$, Kishimoto S: Tumour necrosis factor/cachectin plays a key role in autoimmune pulmonary inflammation in lupus-prone mice. Clin Exp Immunol 1991, 85:392-395.

18. Su X, Zhou T, Yang P, Edwards CK, Mountz JD: Reduction of arthritis and pneumonitis in motheaten mice by soluble tumor necrosis factor receptor. Arthritis Rheum 1998, 41:139-149.

19. Segal R, Dayan M, Zinger H, Mozes E: Suppression of experimental systemic lupus erythematosus (SLE) in mice via TNF inhibition by an anti-TNFalpha monoclonal antibody and by pentoxiphylline. Lupus 2001, 10:23-31.

20. Charles PJ, Smeenk RJ, De Jong J, Feldmann M, Maini RN: Assessment of antibodies to double-stranded DNA induced in rheumatoid arthritis patients following treatment with infliximab, a monoclonal antibody to tumor necrosis factor alpha: findings in open-label and randomized placebo-controlled trials. Arthritis Rheum 2000, 43:2383-2390.

21. Kruithof E, Van Den BF, Baeten D, Herssens A, De Keyser F, Mielants $H$, Veys EM: Repeated infusions of infliximab, a chimeric anti-TNFalpha monoclonal antibody, in patients with active spondyloarthropathy: one year follow up. Ann Rheum Dis 2002, 61:207-212.

22. De Rycke L, Kruithof E, Van Damme N, Hoffman IE, Van den BN, Van Den BF, Veys EM, De Keyser F: Antinuclear antibodies following infliximab treatment in patients with rheumatoid arthritis or spondylarthropathy. Arthritis Rheum 2003, 48: 1015-1023.

23. Garcia-Planella E, Domenech E, Esteve-Comas M, Bernal I, Cabre E, Boix J, Gassull MA: Development of antinuclear antibodies and its clinical impact in patients with Crohn's disease treated with chimeric monoclonal anti-TNFalpha antibodies (infliximab). Eur J Gastroenterol Hepatol 2003, 15:351-354.

24. Ferraro-Peyret C, Coury F, Tebib JG, Bienvenu J, Fabien N: Infliximab therapy in rheumatoid arthritis and ankylosing spondylitis-induced specific antinuclear and antiphospholipid autoantibodies without autoimmune clinical manifestations: a two-year prospective study. Arthritis Res Ther 2004, 6:R535R543.

25. Vermeire S, Noman M, Van Assche G, Baert F, Van Steen K, Esters $\mathrm{N}$, Joossens $\mathrm{S}$, Bossuyt $\mathrm{X}$, Rutgeerts P: Autoimmunity associated with anti-tumor necrosis factor alpha treatment in Crohn's disease: a prospective cohort study. Gastroenterology 2003, 125:32-39.

26. Allanore Y, Sellam J, Batteux F, Job DC, Weill B, Kahan A: Induction of autoantibodies in refractory rheumatoid arthritis treated by infliximab. Clin Exp Rheumatol 2004, 22:756-758.

27. Eriksson C, Engstrand S, Sundqvist KG, Rantapaa-Dahlqvist S: Autoantibody formation in patients with rheumatoid arthritis treated with anti-TNF alpha. Ann Rheum Dis 2005, 64:403-407.

28. De Rycke L, Baeten D, Kruithof E, Van Den BF, Veys EM, De Keyser F: Infliximab, but not etanercept, induces IgM antidouble-stranded DNA autoantibodies as main antinuclear reactivity: biologic and clinical implications in autoimmune arthritis. Arthritis Rheum 2005, 52:2192-2201.

29. Sellam J, Allanore Y, Batteux F, Deslandre CJ, Weill B, Kahan A: Autoantibody induction in patients with refractory spondyloarthropathy treated with infliximab and methotrexate. Joint Bone Spine 2005, 72:48-52.

30. Atzeni F, Ardizzone S, Sarzi-Puttini P, Colombo E, Maconi G, De PS, Carrabba M, Bianchi PG: Autoantibody profile during shortterm infliximab treatment for Crohn's disease: a prospective cohort study. Aliment Pharmacol Ther 2005, 22:453-461.
31. Comby E, Tanaff P, Mariotte D, Costentin-Pignol V, Marcelli C, Ballet JJ: Evolution of antinuclear antibodies and clinical patterns in patients with active rheumatoid arthritis with longterm infliximab therapy. J Rheumato/ 2006, 33:24-30.

32. De Bandt M, Sibilia J, Le L, X, Prouzeau S, Fautrel B, Marcelli C, Boucquillard E, Siame JL, Mariette X: Systemic lupus erythematosus induced by anti-tumour necrosis factor alpha therapy: a French national survey. Arthritis Res Ther 2005, 7:R545-R551.

33. Ferraccioli GF, Assaloni R, Di Poi E, Gremese E, De Marchi G, Fabris M: Rescue of combination therapy failures using infliximab, while maintaining the combination or monotherapy with methotrexate: results of an open trial. Rheumatology (Oxford) 2002, 41:1109-1112.

34. Ferraccioli GF, Assaloni R, Perin A: Drug-induced systemic lupus erythematosus and TNF-alpha blockers. Lancet 2002, 360:645.

35. Colombel JF, Loftus EV Jr., Tremaine WJ, Egan LJ, Harmsen WS, Schleck CD, Zinsmeister AR, Sandborn WJ: The safety profile of infliximab in patients with Crohn's disease: the Mayo clinic experience in 500 patients. Gastroenterology 2004, 126:19-31.

36. Ramos-Casals M, Brito-Zeron P, Munoz S, Soria N, Galiana D, Bertolaccini L, Cuadrado MJ, Khamashta MA: Autoimmune diseases induced by TNF-targeted therapies: analysis of 233 cases. Medicine (Baltimore) 2007, 86:242-251.

37. Carlson E, Rothfield N: Etanercept-induced lupus-like syndrome in a patient with rheumatoid arthritis. Arthritis Rheum 2003, 48:1165-1166.

38. Mor A, Bingham C III, Barisoni L, Lydon E, Belmont HM: Proliferative lupus nephritis and leukocytoclastic vasculitis during treatment with etanercept. J Rheumato/ 2005, 32:740-743.

39. Stokes MB, Foster K, Markowitz GS, Ebrahimi F, Hines W, Kaufman D, Moore B, Wolde D, D'Agati VD: Development of glomerulonephritis during anti-TNF-alpha therapy for rheumatoid arthritis. Nephrol Dial Transplant 2005, 20:14001406.

40. Maury CP, Teppo AM: Tumor necrosis factor in the serum of patients with systemic lupus erythematosus. Arthritis Rheum 1989, 32:146-150.

41. Studnicka-Benke A, Steiner G, Petera P, Smolen JS: Tumour necrosis factor alpha and its soluble receptors parallel clinical disease and autoimmune activity in systemic lupus erythematosus. Br J Rheumatol 1996, 35:1067-1074.

42. Gabay C, Cakir N, Moral F, Roux-Lombard P, Meyer O, Dayer JM, Vischer T, Yazici H, Guerne PA: Circulating levels of tumor necrosis factor soluble receptors in systemic lupus erythematosus are significantly higher than in other rheumatic diseases and correlate with disease activity. J Rheumatol 1997 24:303-308.

43. Davas EM, Tsirogianni A, Kappou I, Karamitsos D, Economidou I, Dantis PC: Serum IL-6, TNFalpha, p55 srTNFalpha, p75srTNFalpha, srlL-2alpha levels and disease activity in systemic lupus erythematosus. Clin Rheumatol 1999, 18:17-22.

44. Aringer M, Stummvoll GH, Steiner G, Koller M, Steiner CW, Hofler E, Hiesberger H, Smolen JS, Graninger WB: Serum interleukin-15 is elevated in systemic lupus erythematosus. Rheumatology (Oxford) 2001, 40:876-881.

45. Aderka D, Wysenbeek A, Engelmann H, Cope AP, Brennan F, Molad Y, Hornik V, Levo Y, Maini RN, Feldmann M: Correlation between serum levels of soluble tumor necrosis factor receptor and disease activity in systemic lupus erythematosus. Arthritis Rheum 1993, 36:1111-1120.

46. Aringer M, Feierl E, Steiner G, Stummvoll GH, Höfler E, Steiner CW, Radda I, Smolen JS, Graninger WB: Increased bioactive TNF in human systemic lupus erythematosus: associations with cell death. Lupus 2002, 11:102-108.

47. Takemura T, Yoshioka K, Murakami K, Akano N, Okada M, Aya N, Maki S: Cellular localization of inflammatory cytokines in human glomerulonephritis. Virchows Arch 1994, 424:459-464.

48. Malide $D$, Russo $P$, Bendayan $M$ : Presence of tumor necrosis factor alpha and interleukin-6 in renal mesangial cells of lupus nephritis patients. Hum Pathol 1995, 26:558-564.

49. Neale TJ, Ruger BM, Macaulay H, Dunbar PR, Hasan Q, Bourke A, Murray-Mclntosh RP, Kitching AR: Tumor necrosis factoralpha is expressed by glomerular visceral epithelial cells in human membranous nephropathy. Am J Pathol 1995, 146: 1444-1454. 
50. Herrera-Esparza R, Barbosa-Cisneros O, Villalobos-Hurtado R, Avalos-Diaz E: Renal expression of IL-6 and TNFalpha genes in lupus nephritis. Lupus 1998, 7:154-158.

51. Aringer M, McInnes IB, Steiner G, Soleiman A, Stöckl-Hiesleitner S, Hoefler E, Meyer B, Ulrich W, Smolen JS: TNF and interleukin-18 (IL-18) upregulation in kidneys and sera of patients with active systemic lupus erythematosus [abstract]. Ann Rheum Dis 2007, 66:108.

52. Zampieri S, Alaibac M, laccarino L, Rondinone R, Ghirardello A, Sarzi-Puttini P, Peserico A, Doria A: Tumour necrosis factor alpha is expressed in refractory skin lesions from patients with subacute cutaneous lupus erythematosus. Ann Rheum Dis 2006, 65:545-548.

53. Smolen JS, Strand V, Cardiel M, Edworthy S, Furst D, Gladman D, Gordon C, Isenberg DA, Klippel JH, Petri M, et al.: Randomized clinical trials and longitudinal observational studies in systemic lupus erythematosus: consensus on a preliminary core set of outcome domains. J Rheumatol 1999, 26:504-507.

54. Elliott MJ, Maini RN, Feldmann M, Long-Fox A, Charles P, Bijl H, Woody JN: Repeated therapy with monoclonal antibody to tumour necrosis factor alpha (cA2) in patients with rheumatoid arthritis. Lancet 1994, 344:1125-1127.

55. Brandt J, Haibel H, Cornely D, Golder W, Gonzalez J, Reddig J, Thriene W, Sieper J, Braun J: Successful treatment of active ankylosing spondylitis with the anti-tumor necrosis factor alpha monoclonal antibody infliximab. Arthritis Rheum 2000, 43:1346-1352.

56. Aringer M, Graninger WB, Steiner G, Smolen JS: Safety and efficacy of TNFa blockade in systemic lupus erythematosus - an open label study. Arthritis Rheum 2004, 50:3161-3169.

57. Gonzalez CM, Lopez-Longo FJ, Monteagudo I, Vazquez-Coleman J, Montoro M, Ortega C, Nuno L, Gonzalez-Diaz de Rabago E, de la Torre-Ortega I, Carreno L: Anti-TNF agents are effective and safe in the management of systemic lupus erythematosus [abstract]. Arthritis Rheum 2004, 50:S412.

58. Micheloud D, Nuno L, Rodriguez-Mahou M, Sanchez-Ramon S, Ortega MC, Aguaron A, Junco E, Carbone J, Fernandez-Cruzl E, Carreno $L$, et al.: Efficacy and safety of Etanercept, high-dose intravenous gammaglobulin and plasmapheresis combined therapy for lupus diffuse proliferative nephritis complicating pregnancy. Lupus 2006, 15:881-885.

59. Aringer M, Houssiau F, Graninger WB, Feierl E, Steiner G, Smolen JS: Long term safety and efficacy of open-label infliximab for SLE [abstract]. Ann Rheum Dis 2007, 66:455.

60. Hayat SJ, Uppal SS: Therapeutic efficacy and safety profile of infliximab in active systemic lupus erythematosus. Mod Rheumatol 2007, 17:174-177.

61. Hayat SJ, Uppal SS, Narayanan Nampoory MR, Johny KV, Gupta $\mathrm{R}, \mathrm{Al}-\mathrm{Oun} \mathrm{M}$ : Safety and efficacy of infliximab in a patient with active WHO class IV lupus nephritis. Clin Rheumatol 2007, 26: 973-975.

62. Aringer $M$, Steiner G, Graninger WB, Hofler E, Steiner CW, Smolen JS: Effects of short-term infliximab therapy on autoantibodies in systemic lupus erythematosus. Arthritis Rheum 2007, 56:274-279.

63. Katz RS, Holt-Daly N, MacDonald PA: Frequent infusion reactions associated with infliximab treatment in patients with polyarthritis related to systemic lupus erythematosus [abstract]. Arthritis Rheum 2003, 48:S379.

64. Hiepe F, Bruns A, Feist E, Burmester GR: Successful treatment of a patient suffering from a refractory subacute cutaneous lupus erthematosus (SCLE) with blockers of tumour necrosis factor a [abstract]. Arthritis Rheum 2004, 50:S413.

65. Norman R, Greenberg RG, Jackson JM: Case reports of etanercept in inflammatory dermatoses. J Am Acad Dermatol 2006, 54:S139-S142.

66. Lejeune FJ: Clinical use of TNF revisited: improving penetration of anti-cancer agents by increasing vascular permeability. J Clin Invest 2002, 110:433-435.

67. Aringer M, Graninger WB, Steiner G, Smolen JS: Safety and efficacy of tumor necrosis factor alpha blockade in systemic lupus erythematosus: an open-label study. Arthritis Rheum 2004, 50:3161-3169.

68. Arbuckle MR, McClain MT, Rubertone MV, Scofield RH, Dennis GJ, James JA, Harley JB: Development of autoantibodies before the clinical onset of systemic lupus erythematosus. $N$ Engl J Med 2003, 349:1526-1533.
69. Palucka AK, Blanck JP, Bennett L, Pascual V, Banchereau J: Cross-regulation of TNF and IFN-alpha in autoimmune diseases. Proc Natl Acad Sci U S A 2005, 102:3372-3377.

70. Via CS, Shustov A, Rus V, Lang T, Nguyen P, Finkelman FD: In vivo neutralization of TNF-alpha promotes humoral autoimmunity by preventing the induction of CTL. J Immunol 2001 167:6821-6826

71. Pittoni V, Bombardieri M, Spinelli FR, Scrivo R, Alessandri C, Conti F, Spadaro A, Valesini G: Anti-tumour necrosis factor (TNF) alpha treatment of rheumatoid arthritis (infliximab) selectively down regulates the production of interleukin (IL) 18 but not of IL12 and IL13. Ann Rheum Dis 2002, 61:723-725.

72. Cope AP, Londei M, Chu NR, Cohen SB, Elliott MJ, Brennan FM, Maini RN, Feldmann M: Chronic exposure to tumor necrosis factor (TNF) in vitro impairs the activation of $\mathrm{T}$ cells through the T cell receptor/CD3 complex; reversal in vivo by anti-TNF antibodies in patients with rheumatoid arthritis. J Clin Invest 1994, 94:749-760.

73. Isomaki $\mathrm{P}$, Panesar M, Annenkov A, Clark JM, Foxwell BM, Chernajovsky $Y$, Cope AP: Prolonged exposure of T cells to TNF down-regulates TCR zeta and expression of the TCR/CD3 complex at the cell surface. J Immuno/ 2001, 166:5495-5507.

74. Casciola-Rosen L, Rosen A, Petri M, Schlissel M: Surface blebs on apoptotic cells are sites of enhanced procoagulant activity: implications for coagulation events and antigenic spread in systemic lupus erythematosus. Proc Natl Acad Sci U S A 1996, 93:1624-1629.

75. Utz PJ, Hottelet M, Schur PH, Anderson P: Proteins phosphorylated during stress-induced apoptosis are common targets for autoantibody production in patients with systemic lupus erythematosus. J Exp Med 1997, 185:843-854.

76. ClinicalTrials.gov home page [http://www.clinicaltrials.gov]. 